\title{
Village Fund Management in Manunggang Julu Village 2017, Southeast Padangsidimpuan Sub-District, Padangsidimpuan, Indonesia
}

\author{
Syulhennisari Siregar \\ Lecturer at Faculty of Social and Political Sciences, Muhammadiyah University of South Tapanuli (FISIP \\ UMTS), North Sumatra, Indonesia \\ syulhennisari.siregar@um-tapsel.ac.id
}

\begin{abstract}
The allocation of village fund is expected to be more optimal in increasing equitable development of village welfare through improving public services in the village, advancing the village economy, overcoming the development gap between villages and strengthening village communities as subjects of development. This paper intends to review and analyze the village fund management in 2017 in Manunggang Julu Village, Padangsidimpuan Sub-district, Southeast Padangsidimpuan. The method used in this writing is a literature review of secondary data collection techniques derived from books, research and journals. This paper concludes that village fund management is carried out on the priority of using funds with the principle of justice, community priority needs and village typology.
\end{abstract}

Keywords: management; village fund; Manunggang Julu Village; Padangsidimpuan

\section{Introduction}

Village fund management is based on Government Regulation Number 60 of 2014 concerning Village Funds sourced from the State Budget that aims to create a developed, independent and prosperous village without having to lose identity through the financing of government administration, implementation of development, community development, and community empowerment.

This village fund is intended for villages that are transferred through the district / city Regional Revenue and Expenditure Budget and are used to finance government administration, implementation of development, community development, and community empowerment. The allocation of village funds is expected to increase equitable development of village welfare through improving public services in the village, advancing the village economy, overcoming the development gap between villages and strengthening village communities as subjects of development.

Village fund management must be carried out openly through village meetings and the results are stated in the Village Regulation (Perdes). The provision shows the commitment of decision makers that the management of funds must comply with the rules of good governance that must be carried out by the actors and the village community. Village fund managementthat have been provided by the government so that they are in accordance with their objectives, it is necessary to implement management functions in each management process. Fund management in Manunggang Julu Village, Padangsidimpuan Subdistrict, Southeast Padangsidimpuan City, there are still several problems, from planning, implementation, to supervision.

To fund every village development activity, there is a significant cost required. In each village village funds are given each year with a certain amount for the purpose of building the village. But some situations in the use of village funds are prone to misappropriation of funds by those who should be trusted by the community in developing villages to become more developed and developing. This is where the importance of the role 
of the community as direct supervisors and cannot be separated from the role of the city government as funders to always monitor the development nets in the village. Where most of the funds are allocated for village development, starting from the fund planning process, managing funds, the reporting must be carried out in accordance with applicable procedures. So that it is hoped that this village fund can create equitable and beneficial development for the village community.

Fund management in Manunggang Julu Village, Southeast Padangsidimpuan Subdistrict, Padangsidimpuan City, there are still a number of problems, from planning, implementation to supervision. This paper will reveal how the management of these funds through literature has been strengthened by analysis from the author.

The purpose of this paper is to find out and analyze the village fund managementin 2017 in Manunggang Julu Village, Padangsidimpuan District, Southeast, Padangsidimpuan City.

\section{Literature Review}

Village funds are one of the important issues in village law. Calculation of the budget is based on the number of villages taking into account the population, poverty rate, area size, and level of geographical difficulties in order to improve welfare and equitable distribution of village development. Because the issue was so important, the senators considered that the implementation of village government needed guidance and supervision, especially the implementation of village activities.

The budget for village funds is a financial part obtained from tax sharing and part of the Central and Regional Financial Balance Funds received by the Regency / city. The overall source of income for the village is used to mark all the authorities that are the responsibility of the village. The funds are used to mark the implementation of village authority that covers the administration of government, development, community empowerment, and community. Thus, income derived from the APBN is also used to mark the authority.

Village funds according to Government Regulation Number 60 of 2014 concerning Village Funds sourced from the State Revenue and Expenditure Budget are funds sourced from the State Revenue and Expenditure Budget intended for villages that are transferred through the district / city Regional Revenue and Expenditure Budget and are used to finance government administration, implementation of development, community development, and community empowerment. (PP. No. 60 in 2014, Article 1 number 2).

The use of the Village Fund is prioritized for the development and empowerment of rural communities, especially for improving quality of life, poverty alleviation and community welfare. Village finance is managed based on good governance practices. Village financial management starts from planning where the first village meeting is held by the Village Consultative Body to discuss matters of a strategic nature. Then, the results of the village discussion in the form of village development planning were followed up with village planning development meetings (musrenbangdes) organized by the village head and his device.

Musrenbangdes that discusses the Mid-Term Village Development Plan (RPJMDes) every six years and the Village Government Work Plan (RKPDes) and the annual APBDes. After the Raperdes about the APBDes agreed upon by the village head and BPD no later than October and the evaluation results from the regent / mayor or sub-district head (who received 
a delegation to evaluate the Raperdes APBDes) stated that the APBDes Raperdes did not conflict with the public interest and higher legislation, APBDes can be set. The use of village funds is managed by the village government through the power of the village head and used in accordance with the RPJMDes, RKPDes, and APBDes.

Village financial management in implementing regulations, the village head is the holder of village financial management. In exercising his power, the village head authorized some of his power to the village apparatus. Management of village finance based on Government Regulation Number 43 of 2014 concerning Implementing Regulations Law Number 6 of 2014 concerning Villages includes: a. planning; b. implementation; c. administration; d. reporting; and e. accountability. (PP No. 43 in 2014, Article 93 paragraph 1).

The principles of village financial management are contained in the Minister of Home Affairs Regulation No. 113 in 2014 concerning Village Financial Management, namely: (1) Village finance is managed based on transparent, accountable, participatory principles and carried out in an orderly and budgetary discipline. (2) Management of village finance as referred to in paragraph (1), is managed within a period of 1 (one) fiscal year, starting from January 1 to December 31. (Minister of Internal Affairs regulations, No. 113 in 2014, Article 2). Further principles of village financial management include:

1. Transparent

Open-openness, in the sense that all activities and information related to village financial management can be known and monitored by other authorized parties.

2. Accountable

Every action / performance of the government / institution can be accounted for to those who have the right or authority to ask for information on accountability.

3. Participatory

Every action is carried out by involving the involvement of the community both directly and indirectly through representative institutions that can channel their aspirations.

4. Order and Budget Discipline

The budget must be carried out consistently by recording its use in accordance with the principles of financial accounting in the village. (Technical Guidance for Village Government Management, 2017).

Prioritizing the use of village funds is explained in the Village Minister's Regulation, Underdeveloped Regional Development, and Transmigration Number 4 in 2017 concerning Amendments to Village Minister Regulation, Development of Disadvantaged Regions, and Transmigration Number 22 in 2016 concerning Priority Determination of Village Funds for 2017, namely:

(1) Priority for the use of village funds to finance the implementation of programs and activities in the field of village development and empowerment of rural communities.

(2) Priority for the use of village funds is prioritized to finance the implementation of cross-field programs and activities.

(3) Programs and activities as referred to in paragraph (2) are mainly fields of BUMDesa or BUMDesa Bersama activities, bloated, superior Village products or rural areas and village sports facilities. 
(4) Priority for the use of village funds as referred to in paragraph (1), is published to the public by the village government in the public space or space accessible to the village community. (Permendes, PDT and Transmigration No. 4 Year 2017. Article 4).

\section{Findings and Discussion}

\subsection{Village Fund Management with Transparent Principles}

Transparency is a principle of openness that allows people to know and get access to information as widely as possible about regional finance. With the existence of transparency, it will guarantee access or freedom for everyone to obtain information about the administration of government, namely information about policies, manufacturing processes, and their implementation as well as the results that have been achieved.

Transparency means that the village administration manages finances openly, because finance is owned by the people or public goods that must be known by the community. The village government must submit information openly to the public. Openness will increase community trust and respect for the village government. Transparency of village fund management in Manunggang Julu Village for all of its applications in accordance with Permendagri Number 113 in 2014, namely the activities of recording cash in and out which can be easily accessed by the community and there is an announcement board regarding the activities being carried out. Likewise, the realization of reports and accountability reports on the realization of the APBDA village were informed to the public in writing and with information media that were easily accessed by the community, as well as realization reports and accountability reports on the realization of village funds submitted to the Regent/Mayor through the Camat.

In fact, the transparency of the management of the village fund in Manunggang Julu Village for its implementation has not been in accordance with Permendagri Number 113 in 2014 due to the absence of cash in and out recording activities that can be easily accessed by the community and the absence of announcement boards regarding the activities being carried out. Only with the realization of the report and the accountability report for the realization of the APBDesa that the community informed through a meeting forum with the BPD and LPMD, as well as the realization report and accountability report on the realization of the ADD implementation delivered to the Regent / Mayor through the Camat.

Furthermore, the lack of transparency in financial management can be seen from the disordered and well-organized financial administration, the existence of certain funds flow (non budgeter / tactical funds / funds that are not included in the budget), which only a few people know, keep information confidential, and ignorance of the public these funds. This gives the freedom of the occurrence of irregularities / abuses by unscrupulous officers which have fatal consequences for the community and the apparatus concerned.

Thus, the principle of transparency guarantees the right of all parties to know the whole process at each stage and ensure access of all parties to information related to the management of village funds. Transparency thus means the pro-village government is active and makes it easy for anyone, at any time to access / get / know information regarding village fund management.

\subsection{Village Fund Management with Accountable Principles}

Accountability has the aim of improving the performance of village administrations with tasks assigned to improve the value and quality of service activities for the community. 
Assessing the performance of the village government in carrying out its duties and responsibilities in accordance with applicable laws and regulations.

Accountability in the planning, implementation, administration and reporting and accountability of village fund management in Manunggang Julu Village in its implementation has been guided by Permendagri Number 113 in 2014. Where the village fund managementis in accordance with procedures for managing the funds through the stages of planning, implementation, administration, and reporting and accountability.

The accountability of the village government for the village funds is intended to be a Realization Report, which is a form of village government accountability for managing village funds that is reported twice a year or every semester of the year. But in its implementation, Manunggang Julu Village experienced delays in its reporting, namely in September. The Realization Accountability Report for the Implementation of the Village Budget is the responsibility of the village administration for the village fund managementin detail, which is shown to the trustee, which of course is to be more transparent and accountable about all activities carried out on the fund. Whereas the Realization Accountability Report for the Village Budget is reported at the end of each fiscal year.

\subsection{Village Fund Management with Participatory Principles}

The implementation of development which covers all aspects of new life will succeed if it is an activity involving all members of the community. Participation from each element of society is needed so that development is in accordance with the needs of the community. The stages in the process of managing village funds in Manunggang Julu Village often overlap, as in one community meeting meeting can occur directly several stages, namely the stages of planning, implementation, utilization, and evaluation. This uniqueness can certainly reduce the effectiveness of meetings held because there is too much information that must be accepted and understood by the community, as well as irregular topics of discussion, making it difficult for the community to sort the appropriate information.

For this reason, the achievement of village funds still requires improvement, namely planning, managing, and supervising village funds in the future will be even heavier. So that the government always strives for village funds to be more pro-people and produce a transparent, accountable and participatory village fund management system and the government's goals through the allocation of village funds can be realized. Then it is necessary to strengthen institutional capacity and human resources, both village government officials, the community, and village assistance staff as well as improving transparency, accountability and participatory management of village funds.

\section{Conclusion}

Village fund management in 2017 in Manunggang Julu Village on the principle of transparency of village fund management is still not seen from the unorganized and good financial administration, the existence of certain funds flow (non budgeter / tactical funds / funds not included in the budget), which is only known a handful of people, keep information confidential, and the public ignorance of these funds. Then in the accountable principle, it can be seen from the form of village government accountability towards the village fund such as the Report on the realization of the management of the village fund experiencing delays in reporting. 
Village fund management from participatory principles also often often overlaps, as in one community meeting meeting can occur directly several stages, namely the stages of planning, implementation, utilization, and evaluation. This can reduce the effectiveness of meetings held because there is too much information that must be accepted and understood by the community, as well as irregular topics of discussion, making it difficult for the community to sort the appropriate information.

\section{References}

Government Regulation Number 60 in 2014 concerning Village Funds Sources from the State Budget.

Minister of Home Affairs Regulation No. 113 in 2014 concerning Village Financial Management

Government Regulation Number 43 in 2014 concerning Implementing Regulations Law Number 6 Year 2014 concerning Villages.

Village Governance Technical Guidance, Village Finance Implementation Procedures and Village-Owned Goods/Asset Management Strategies, Village Government Management, 2017.

Village Minister Regulation, Development of Disadvantaged Regions, and Transmigration Number 4 in 2017 concerning Amendments to Village Minister Regulations, Development of Disadvantaged Regions, and Transmigration Number 22 in 2016 concerning Priority Determination of Village Fund Use in 2017. 